Article

\title{
Application of Entrepreneurial Intention Model in Comparative International Entrepreneurship Research: A Cross-Cultural Study of India and Saudi Arabia
}

\author{
Najmul Hoda ${ }^{1}$, Naim Ahmad ${ }^{2, *}$ (D) Shankar Lal Gupta ${ }^{3}$, Mohammad Mahtab Alam ${ }^{4}$ and Irfan Ahmad ${ }^{5}$ (i) \\ 1 Department of Business Administration, College of Business, Umm Al-Qura University, \\ Makkah 21955, Saudi Arabia; nnhoda@uqu.edu.sa \\ 2 Department of Information Systems, College of Computer Science, King Khalid University, \\ Abha 62529, Saudi Arabia \\ 3 Faculty of Management, Birla Institute of Technology, Noida 201301, India; drslgupta@gmail.com \\ 4 Department of Basic Medical Sciences, College of Applied Medical Sciences, King Khalid University, \\ Abha 62529, Saudi Arabia; mabuhashra@kku.edu.sa \\ 5 Department of Clinical Laboratory Sciences, College of Applied Medical Sciences, King Khalid University, \\ Abha 62529, Saudi Arabia; irfancsmmu@gmail.com \\ * Correspondence: nagqadir@kku.edu.sa
}

check for updates

Citation: Hoda, N.; Ahmad, N.; Gupta, S.L.; Alam, M.M.; Ahmad, I. Application of Entrepreneurial Intention Model in Comparative International Entrepreneurship Research: A Cross-Cultural Study of India and Saudi Arabia. Sustainability 2021, 13, 13369. https://doi.org/ $10.3390 /$ su132313369

Academic Editor: Fernando Almeida

Received: 20 October 2021

Accepted: 30 November 2021

Published: 2 December 2021

Publisher's Note: MDPI stays neutral with regard to jurisdictional claims in published maps and institutional affiliations.

Copyright: (c) 2021 by the authors. Licensee MDPI, Basel, Switzerland. This article is an open access article distributed under the terms and conditions of the Creative Commons Attribution (CC BY) license (https:/ / creativecommons.org/licenses/by/ $4.0 /)$.

\begin{abstract}
The development of entrepreneurial activities helps in realization of multiple goals of sustainable development. This study aims to inspect the applicability of the entrepreneurial intention model (EIM) to explain entrepreneurial intention in different cultural contexts. A survey was conducted using the Entrepreneurial Intention Questionnaire. Based on 535 valid responses received from business students in India $(\mathrm{N}=285)$ and Saudi Arabia $(\mathrm{N}=250)$, the model was analyzed using the partial least square regression method. The results show that the EIM is validated for the combined sample $\left(\mathrm{R}_{\text {combined }}^{2}=0.522\right)$ as well as for the individual samples $\left(\mathrm{R}^{2}\right.$ India $=0.644$; $\mathrm{R}^{2}$ Saudi $=0.412$ ). Demographic variables and human capital variables were found to impact the entrepreneurial intention differently in the combined sample and the individual samples of the two countries. Multigroup analysis was performed to test if the country variable influences the hypothesized paths in the model. The results of the multigroup analysis show that many of the hypothesized relationships (gender-personal attitude; gender-subjective norm; gender-perceived behavioral control, role model-subjective norm, role model-perceived behavioral control, subjective norm-personal attitude, and subjective norm-entrepreneurial intention) are significantly different in the two countries. This study addresses the gap in comparative international entrepreneurship (CIE) research by testing the applicability of EIM in two different cultures. The findings are also significant for policymakers at both national and international levels for facilitating entrepreneurship.
\end{abstract}

Keywords: entrepreneurial intention; Theory of Planned Behavior (TPB); Entrepreneurial Intention Model (EIM); entrepreneurial intention questionnaire; comparative international entrepreneurship (CIE)

\section{Introduction}

Economic development and entrepreneurship have been considered to be closely related to each other [1,2]. Entrepreneurs contribute to a nation's growth in many ways such as innovation, employment generation, better resource utilization, wealth distribution, and societal well-being [3,4]. The entrepreneurial activities may help in realization of multiple sustainable development goals such as alleviate poverty, gender equality, bridge inequality among countries. Hence, it has been specifically targeted under the goals of equitable education and equitable work environment [5].

The role of entrepreneurship in the socio-economic development of developing countries is well supported in research [6,7]. A popular strand of entrepreneurship research has been the understanding of reasons why an individual decides to become an 
entrepreneur [8-11]. Research has supported the theory that being an entrepreneur is a planned action that is preceded by a "cognitive state" [12], famously known as "intention" $[2,13]$. Ajzen [13] is credited with theorizing the relationship between "intention" and "action", popularly called the Theory of Planned Behavior. This theory has been applied to entrepreneurship as well and has been found to successfully explain the intention to become an entrepreneur or the "Entrepreneurial Intention" $[11,13,14]$. Entrepreneurship research has found several other theoretical models that help explain EI, including the Entrepreneurial Intention Model developed by Linan and Chen [14]. EIM has been adapted from the theory of planned behavior by adding the demographic and human capital variables in addition to including the indirect effect of subjective norms on entrepreneurial intention.

Research on entrepreneurial intention of students is overwhelming [1,2,15-18]. One of the major reasons for this is the emphasis of policymakers on increasing new businesses to overcome youth unemployment and economic growth [2]. Policymakers have been targeting university students to promote entrepreneurship because they can be easily influenced during their career selection [19]. More specifically, business graduates have been found to be more ambitious in starting their own venture [19]. Therefore, student population has been the prime target of entrepreneurial research [20].

Maalaoui et al. [21] classified EI research into three types namely, studies exploring antecedents of EI; explaining the conversion of intention to action; and improving the model by adding new variables. Studies have found the role of culture in entrepreneurial behavior as well as new venture creation [22,23]. A cross-cultural understanding of entrepreneurial behavior also has a "cognitive and utilitarian value" [24]. It may provide deeper insights into the "causative factors of entrepreneurship" in different national and cultural contexts [25].

A particular strand of entrepreneurship research dealing with a cross-cultural or international perspective has been named as comparative international entrepreneurship (CIE) $[24,26]$. It is characterized by its focus on entrepreneurial behaviors in different countries and cultures $[1,14,27-29]$. The CIE research is a part of the broad area of international entrepreneurship (IE). Several studies have pointed to the need for more research in all the areas of IE, including CIE. More specifically, researchers point to the need to focus on neglected/under-represented countries/regions in the CIE research [25]. Therefore, there is a need to consider the student population from developing and under-developed countries. The cross-cultural studies can test and establish the generalizability of the models $[14,30,31]$. The role of culture in career intentions of students is also required to understand the predictors of intentions [32]. The article [33] mentioned compelling reasons for conducting a cross-cultural validation of the entrepreneurial intention model. A cross-cultural examination of the model will reveal if the antecedents are or are not affected by culture or the country of origin.

Considering university student populations in two developing countries namely Saudi Arabia and India, the present study addresses the need for more cross-cultural research on entrepreneurial intention. The current research has used Linan and Chen's Entrepreneurship Intention Model [14]. The model along with the instrument have been tested in a variety of samples. The main research questions (RQ) dealt in the current study may be listed as follows:

RQ1: Can the entrepreneurial intention model (EIM) explain entrepreneurial intention of students in different cultural contexts?

RQ2: Does culture affect the relationship between the main antecedents of entrepreneurial intention namely "personal attitude (PA), perceived behavioral control (PBC), and subjective norms $(S N)$ with entrepreneurial intention (EI)"?

RQ3: How do demographic and human capital variables included in the EIM affect the antecedents of entrepreneurial intention (EI) in general and in cultural perspectives? 
The rest of the paper is organized as follows. Section 2 presents the literature review. Section 3 describes the materials and methods. Section 4 illustrates the analysis and results. Section 5 completes the article with discussions and conclusion.

\section{Literature Review}

\subsection{Entrepreneurial Intention Model}

Entrepreneurial intention (EI) as a behavioral construct has several definitions. It has been defined as "the attempt to create new businesses, including self-employment or the expansion of an existing business by an individual, a team of individuals or an already established business" [32,34]. Entrepreneurial intention has been more precisely defined in terms of commitment to start a business [35]. Entrepreneurship research has found several theoretical models that help in explaining EI. Some of the models identified in the literature survey are "the Theory of Planned Behavior (TPB) [13]; Luthje and Franke's model [36]; Entrepreneur Event Model [37]; social networking theory [38]". Among these models, TPB has been the most popular [39-41]. Theory of planned behavior has generally been validated in EI research [12]. It has also been applied in cross-cultural research [42,43], as well as in longitudinal studies [12]. This theory explains intention to be formed by three determinants, namely attitude toward the behavior, subjective norm and perceived control over the behavior. Attitude toward behavior refers to the experience or appraisal of the individual towards the proposed action. Subjective norm depends upon the perception of others towards that action. The third determinant perceived behavioral control is the individual's perception of the viability to perform that action. Lortie and Castogiovanni [44] mention that TPB has generally been used in adapted form in the EI research. Researchers added or adapted the TPB model to explain EI in different contexts [45-47].

The entrepreneurial intention model (EIM) is an adaptation of TPB developed by Linan and Chen [14]. The antecedents of EI are called "personal attitude (PA), perceived behavioral control (PBC) and subjective norms (SN)". Personal attitude means the personal liking of an individual for entrepreneurship, perceived behavioral control implies the firm belief of an individual about his/her success as an entrepreneur, and subjective norms are the notions an individual has about others' perceptions about entrepreneurship [32].

\subsubsection{Personal Attitude and Entrepreneurial Intention}

Personal attitude or attitude towards entrepreneurship is the "personal valuation", "tendency", or attractiveness of an individual in opting for entrepreneurship [13,42]. This valuation may be positive or negative, but it may vary in degree based on the contextual factors [14]. Vamvaka [48] equated entrepreneurship with self-employment that is different from being "organizationally employed". Research shows a direct and positive relationship between attitude and EI $[4,12,18,49,50]$. It has been mentioned that this antecedent of EI comes into play even before a student or an individual starts evaluating business ideas [50]. Further it is elaborated that this factor represents an individual's expectation of positive results, and people with such evaluation of entrepreneurship may create their own venture [51]. An individual's expectations that lead to the personal attitude can also vary. These expectations or rewards are termed "intrinsic" and "extrinsic" [51].

As one of the three antecedents of EI in the EIM, we hypothesize the following:

Hypothesis 1 (H1). Personal Attitude positively affects entrepreneurial intention.

\subsubsection{Subjective Norms and Entrepreneurial Intention}

Subjective norm is the perception of an individual regarding the approval or disapproval of others for their decision to start their own business [2]. It is also a perception of the "social appropriateness" for engaging in entrepreneurship [52]. This factor includes seeking "suggestions and support" from an individual's close connections [20]. Extant research has reported mixed results regarding the direct impact of this antecedent on EI [2]. Some confirm it $[27,51]$ while others reported no significant impact $[6,14,15,53]$. 
In a cross-cultural study [43] that included twelve countries, subjective norms showed significant effect.

We therefore hypothesize the following:

Hypothesis 2a (H2a). Subjective norm positively affects entrepreneurial intention.

Because the impact of subjective norms on EI is not universally established, researchers also considered the indirect effect of subjective norms. In the entrepreneurial intention model, Linan and Chen tested the effect of subjective norm on the factors personal attitude and perceived behavioral control [14]. These two relationships were included in the adapted model of EI called EIM.

We therefore hypothesize the following:

Hypothesis $\mathbf{2 b}$ (H2b). Subjective norm (SN) positively affects personal attitude (PA).

Hypothesis 2c (H2c). Subjective norm (SN) positively affects perceived behavioral control (PBC).

\subsubsection{Perceived Behavioral Control and Entrepreneurial Intention}

The third antecedent of EI included in the EIM is called the "perceived behavioral control". It is the perception of ease or difficulty to start a business [2,13]. Perceived behavioral control is said to be "situational and behavior-specific" [54], and it represents the controllability of the behavior [51]. More simply, this factor represents the ability to do business and control over it [52]. Further, the study [2] highlights the importance of this antecedent in awareness and control of the factors related to success of a venture. Positive impact of perceived behavioral control on EI is reported in numerous studies $[12,27,48,55,56]$. We therefore hypothesize the following:

Hypothesis 3 (H3). Perceived behavioral control positively affects entrepreneurial intention.

\subsection{Demographic Factors, Human Capital and Entrepreneurial Intention}

Apart from the adaptation in the relationship of subjective norms with EI, the EIM also included demographic factors and human capital [14]. Demographic and human capital variables included in the model are "gender, role model, work experience and years of business education". Each of these factors are discussed below.

\subsubsection{Gender}

The impact of gender on EI has been found to be significant [27,57,58]. A study dealing with the EI of students in UAE [59] also confirmed that gender affects EI. Research suggests that among the male and female population, the interest for entrepreneurship is higher in males $[48,60]$. They also add that the males show higher perception towards all the three antecedents of EI compared to females.

Consequently, we hypothesize the following:

Hypothesis 4a (H4a). Gender positively affects personal attitude.

Hypothesis $4 \mathbf{b} \mathbf{( H 4 b )}$. Gender positively affects subjective norm.

Hypothesis 4c (H4c). Gender positively affects perceived behavioral control. 


\subsubsection{Role Model}

Role models, in terms of career decisions, are defined as "those who can encourage others to pursue certain career paths or pursue certain goals" [61]. A historical detail of role models shared by Yang [62] shows that the term was first introduced by Robert K Merton in 1957. Bosma et al. [63] defined role models as "individuals who provide examples for other people to emulate, and who stimulate or inspire to make decisions of others' career as well as attain certain goals". The role models inspire others, and they may be categorized as "partial, stage, option, charismatic and negative" [64].

The influence of role models in entrepreneurship has been proven in research [63]. These role models may also help in the development of the enterprise. Several entrepreneurial studies have highlighted the influence of role models in entrepreneurial intention $[65,66]$.

Earlier studies that included this variable in the entrepreneurial intention models are by $[35,67]$. In Linan and Chen's EIM, this variable was included as one of the human capital variables [14]. It is empirically established in entrepreneurial research that role models do influence an individual's EI significantly [65,68-70]. Role models may impact the "cognitive or emotional process" of an individual that is the antecedent of EI included in EIM [68,71,72]. Further, role models also provide information as well as means to tackle frustration. Fellnhofer [72] also suggested that even the online role models can positively impact an individual's EI.

Consequently, we hypothesize the following:

Hypothesis 5a (H5a). Role model positively affects personal attitude.

Hypothesis $\mathbf{5 b}(\mathbf{H} 5 \mathbf{b})$. Role model positively affects subjective norm.

Hypothesis 5c (H5c). Role model positively affects perceived behavioral control.

\subsubsection{Self-Employment Experience}

Self-employment or prior entrepreneurial experience implies the exposure of an individual to entrepreneurship [73]. This factor has been included as a predictor of EI in entrepreneurship research and is suggested to have influence on EI [74,75]. Hockerts [76] studied the impact of prior experience in intending to start a social enterprise. A type of prior experience through family business was also considered in research [77]. Gird and Bagraim [78] confirmed the positive influence of self-employment experience on EI of students. Linan and Chen [14] included this variable as a predictor of the three antecedents of EI.

Accordingly, we hypothesize the following:

Hypothesis 6a (H6a). Self-employment experience positively affects personal attitude

Hypothesis $\mathbf{6 b}$ (H6b). Self-employment experience positively affects subjective norm.

Hypothesis 6c (H6c). Self-employment experience positively affects perceived behavioral control.

\subsubsection{Business Education}

Business education includes learning various aspects of business including entrepren eurship that may also be a specialization. Direct effect of business education on EI has not been established [79], but its impact on the antecedents of EI has been confirmed in several studies [80-82]. Research suggests that the influence of business education on EI may vary by country [83]. The number of years an individual is exposed to business and entrepreneurial education is an important measure of this variable.

Accordingly, we hypothesize the following: 
Hypothesis 7a (H7a). Years of business education positively affects personal attitude.

Hypothesis $\mathbf{7 b} \mathbf{( H 7 b ) . ~ Y e a r s ~ o f ~ b u s i n e s s ~ e d u c a t i o n ~ p o s i t i v e l y ~ a f f e c t s ~ s u b j e c t i v e ~ n o r m . ~}$

Hypothesis 7c (H7c). Years of business education positively affects perceived behavioral control.

\subsection{Comparative International Entrepreneurship}

International Entrepreneurship (IE) is the strand of research dealing with entrepreneu rial behavior and activities across nations and borders [84]. IE research is a new area that has gained prominence in the last decade [24]. It deals with entrepreneurship across borders and includes "internationalisation and international comparisons of domestic entrepreneurship in many countries" [85]. This research area has also been projected to be called an "independent scientific discipline" [23,84,86]. Zahra [87] made a notable contribution to the IE research by extending the focus beyond just internationalization of enterprises.

Comparative international entrepreneurship (CIE) is a field of entrepreneurship research that deals with entrepreneurship in different countries [24,26]. McDougall and Oviatt [88] were the early proponents of CIE research. Glodowska mentions that CIE research was first included in the area of IE research by Jones [23]. They also add that in terms of chronology, the order in which IE research progressed is "internationalization, comparisons of entrepreneurship and comparative entrepreneurial internationalization" [23].

Two typologies of CIE research were found in the literature survey. The first typology, proposed by Oviatt and McDougall [85], was included in a review article by Terjesen [26]. As per this typology, CIE research may be divided into either a comparison of entrepreneurs or their behaviors. Caviello [89] classified CIE research into three types, namely "Type A: Entrepreneurial internationalization; Type B: International comparisons of entrepreneurship (countries and cultures); and Type C: Comparative entrepreneurial internationalization". [84] used the IE research typology given by Jones (2011) and IE research field classification by [90] to review articles on IE. They found that the share of CIE research is just $14.8 \%$.

A lack of consistency in CIE research has been noted leading to a "scientific immaturity" of the IE research [24]. However, they emphasize that it is an extremely prospective research area. A systematic review by Terjessen, et al. [26] is an important contribution in the literature on CIE.

Comparison of India and Saudi Arabia

India and Saudi Arabia are two prominent developing countries of the Asian continent. They have similarities as well as dissimilarities (Table 1). The population of the two countries are significantly different. India has a population of 1.33 billion people whereas Saudi Arabia has a population of 34.3 million [91]. The real gross domestic product growth for 2020-21 for India and Saudi Arabia is $8.8 \%$ and 3.1\%, respectively [92]. This means that India is growing at a faster pace than Saudi Arabia. The Indian economy is much more diversified compared to that of Saudi Arabia. The International Conference of Labor Statisticians (ICLS) consider the unemployed as "those persons of working age who are without work, seeking work (carried out activities to seek employment during a recent past period), and currently available for work" [93]. The unemployment rate for India and Saudi Arabia are almost the same at $5.4 \%$ and $5.9 \%$, respectively [91]. India has been categorized as a lower-middle-income country, whereas Saudi Arabia is a high-income country [94]. Both countries have been trying to reduce unemployment by supporting entrepreneurship. The "total early-stage entrepreneurship" activity is defined as the percentage of the adult population engaged in entrepreneurship [94]. The percentages for India and Saudi Arabia are $14.97 \%$ and $13.96 \%$, respectively. 
Global Entrepreneurship Monitor (GEM) has developed a national entrepreneurship context index (NECI) that is a composite rating of various countries based on twelve entrepreneurship conditions [94]. The National Entrepreneurship Context Index (NECI) was created by Global Entrepreneurship Monitor in 2019. It represents "the average state of the entrepreneurial environment conditions of a country or territory in which it has been measured" [95]. It is also measured by the NES questionnaire. It reflects the "ease of starting and developing a business" in a particular country [96]. The NECI index includes twelve pillars, namely "entrepreneurial finance, government policies (support and relevance), government policies (taxes and bureaucracy), government entrepreneurship programs, entrepreneurial education at school stage, entrepreneurial education at post-school stage, research and development (R\&D) transfer, commercial and legal infrastructure, internal market dynamics, internal market burdens, physical infrastructure and cultural and social norms" [95]. On this index, the current ranking of India is 5th with a score of 5.8, and Saudi Arabia is ranked 17th with a score of 5.04.

Based on ranking by World Economic Forum, India ranks 68th whereas Saudi Arabia ranks 36th in "global competitiveness" [94]. These data show that both countries are comparable on many parameters of entrepreneurship conditions.

A comparison of the two countries on Hofstede's cultural dimensions, Hofstede, Hofstede, and Michael, 2010, shows that they differ from each other on these dimensions but to varying degrees. The six dimensions in Hofstede's framework are "individualism/collectivism, power distance, uncertainty avoidance, masculinity/femininity, longterm/short-term orientation, and indulgence/restraint" [97]. It may be inferred by looking at the scores that the two countries are quite different from each other on most of the six dimensions.

Table 1. Comparison of India and Saudi Arabia.

\begin{tabular}{ccc}
\hline & India & Saudi Arabia \\
\hline Population (million) [98] & 1.33 billion & 34.3 million \\
\hline Real GDP forecast [98] & $8.8 \%$ & $3.1 \%$ \\
\hline GDP per capita [98] & US\$2099 & US\$23,139 \\
\hline UN classification [99] & Lower middle income Income \\
\hline Youth unemployment [100] & $5.4 \%$ & $5.9 \%$ \\
\hline Total Entrepreneurial Activity Rate [101] & $14.97 \%$ & $13.96 \%$ \\
\hline National Entrepreneurship Context (NECI) Index [101] & 5.8 & 5.04 \\
\hline Global competitiveness ranking [102] & 68 & 36 \\
\hline
\end{tabular}

Studies comparing different countries or regions identified through the literature review are listed in Table 2.

Differences in the model elements or variances have been reported in cross-cultural studies on EI [43]. More studies are required to test the applicability of EIM in CIE research $[28,103]$. This study aims to investigate the applicability of EIM in CIE research by analyzing the influence of a country on various hypothesized paths. 
Table 2. Cross-cultural studies on EI.

\begin{tabular}{|c|c|c|}
\hline Authors & Countries & Theoretical Model \\
\hline DePillis 2007 [104] & USA and Ireland & Personality traits \\
\hline Paul 2016 [31] & India and Japan & Self-developed multifactor \\
\hline Linan 2006 [105] & Spain and Taiwan & EIM \\
\hline Uslay 2002 [106] & USA, Turkey and Spain & ТPB \\
\hline Cruz et al. [103] & Brazil and Portugal & ТPB \\
\hline Autio 1997 [42] & USA, Finland and Sweden & ТРВ \\
\hline Bogatyreva 2019 [54] & Various countries of Europe and Asia. & Self-developed based on Hofstede \\
\hline Moriano 2012 [107] & Various countries of Europe and Asia & ТPB \\
\hline Hueso 2020 [30] & UK and Spain & TPB \\
\hline Trivedi 2017 [9] & India Malaysia Singapore & $\begin{array}{l}\text { Entrepreneurial Intention Constraint Model } \\
\text { (EICM) }\end{array}$ \\
\hline Martínez-González 2019 [32] & Spain and Poland & ТPB \\
\hline Nieuwenhuizen 2015 [108] & South Africa and Poland & ТРВ \\
\hline Bouncken 2009 [109] & Germany and Poland & Self-developed based on Hofstede \\
\hline Ozaralli 2016 [33] & USA and Turkey & ТРB \\
\hline Brancu 2015 [110] & Romania and Iceland & Self-developed based on Hofstede \\
\hline Kibler 2019 [111] & Austria and Finland & ТPB \\
\hline Engle 2010 [43] & Various European, Asian countries and USA. & TPB \\
\hline
\end{tabular}

Therefore, we hypothesize the following:

Hypothesis 8 (H8). Country significantly affects the paths in the entrepreneurial intention model.

\section{Materials and Methods}

\subsection{Survey Instrument: Design and Procedure}

To measure EI, the entrepreneurial intention questionnaire [14] was used. This scale measures the four constructs of TPB, namely "personal attitude, subjective norm, perceived behavioral control, and EI". A number of studies have validated EIQ [28,49]. In India, the available English version of EIQ was employed. For Saudi Arabia, the Arabic version of the instrument was developed with the help of an expert Arabic translator. Thereafter, the instrument was pilot tested with 10 students to establish the validity of the constructs and its items. Based on their input, slight modification was done to generate an exact response.

\subsection{Target Population}

The target population consists of business management students enrolled in bachelor and master programs in India and Saudi Arabia. Their approximate numbers are estimated to be 713 thousand in India [112] and 430 thousand in Saudi Arabia [113,114]. Therefore, the total targeted population in both countries is 1143 thousand.

\subsection{Sample Size}

The minimum required sample size was calculated with the following formula:

$$
n=\frac{z^{2}(p)(q)}{e^{2}}
$$

where, $n=$ sample size; $z=1.96$ ( $z$ table value with 0.05 significance level); $p=$ prevalence level 0.5 (prevalence level is unknown); $q=1-p ; e=$ error term 0.05 (significant level 0.05 ) 
The value of $n$ was calculated with above mentioned values as follows:

$$
\begin{gathered}
n=\frac{1.96^{2}(0.5)(0.5)}{0.05^{2}} \\
n=384.16
\end{gathered}
$$

The value of minimum required sample size was further validated with the online Raosoft calculator [115]. The required minimum sample size for the target population of 1143 comes out to be 385 that is approximately the same as in Equation (3).

\subsection{Sampling Techniques}

The nonprobability convenient sampling was used to extract the required number of respondents from the target population.

\subsection{Inclusion Criteria}

i. Valid response from the perspective of data accuracy

ii. Response from the targeted population

\subsection{Exclusion Criteria}

i. Incomplete response

ii. Duplicate response

iii. Students from other programs

\subsection{Time Frame for Online Survey Process}

Initially, the link of the survey using Google Form was distributed among target students in both countries through the academic staff using emails. The staff intern shared the link with their students by various means such as emails, learning management systems and social networking. For India in the first attempt in the month of June 2020, 50 percent of the data was collected, and in the second attempt in the month of July 2020, the remaining data was collected. Similarly, in Saudi Arabia in the first attempt within the first and second weeks of the month of June 2020, most of the responses were received.

\subsection{Statistical Tools for Data Analysis}

The statistical tools used for the data analysis are as follows:

i. Descriptive statistics for frequency and percentage with the help of SPSS to know the sociodemographic comparison of respondents.

ii. Measurement model was assessed with the help of outer loading (OL $\geq 0.7)$, composite reliability (CR $\geq 0.85)$, average variance extracted (AVE $\geq 0.5)$ and FornellLarcker discriminant validity using SmartPLS [116].

iii. Structural model was evaluated using coefficient of determination (R- square) for endogenous variables, path coefficients, and statistical significance through bootstrapping [117].

iv. Multigroup analysis

a. A three step (configural invariance, compositional invariance, and invariance of mean and variance) for measurement of invariance of composite model (MICOM) analysis as a precondition for multigroup analysis is conducted [118-120].

b. Multigroup analysis for comparison of both countries using path coefficient of both subsamples, their differences and significance of difference. 


\section{Analysis and Results}

Firstly, the descriptive statistics for frequency and percentage were analyzed with the help of SPSS software to know the sociodemographic comparison of respondents. Thereafter, the EIM as represented in Figure 1 was analyzed with SmartPLS (v3.3.2) software (SmartPLS GmbH, Bonningstedt, Germany) [121]. Five routines of this software were utilized, namely PLS algorithm, bootstrapping, blindfolding, permutation, and multigroup analysis. The settings of the routines were kept default except for a maximum number of iterations for the PLS algorithm set at 1000 and samples for bootstrapping set at 5000 and samples for permutation set at 5000. The overall analysis was conducted in two steps. First, the measurement model was assessed for "reliability and validity" based on the total sample. In the second step, the structural model was assessed. Finally, the permutation and multigroup analysis was done to test the differences in the samples of the two countries.

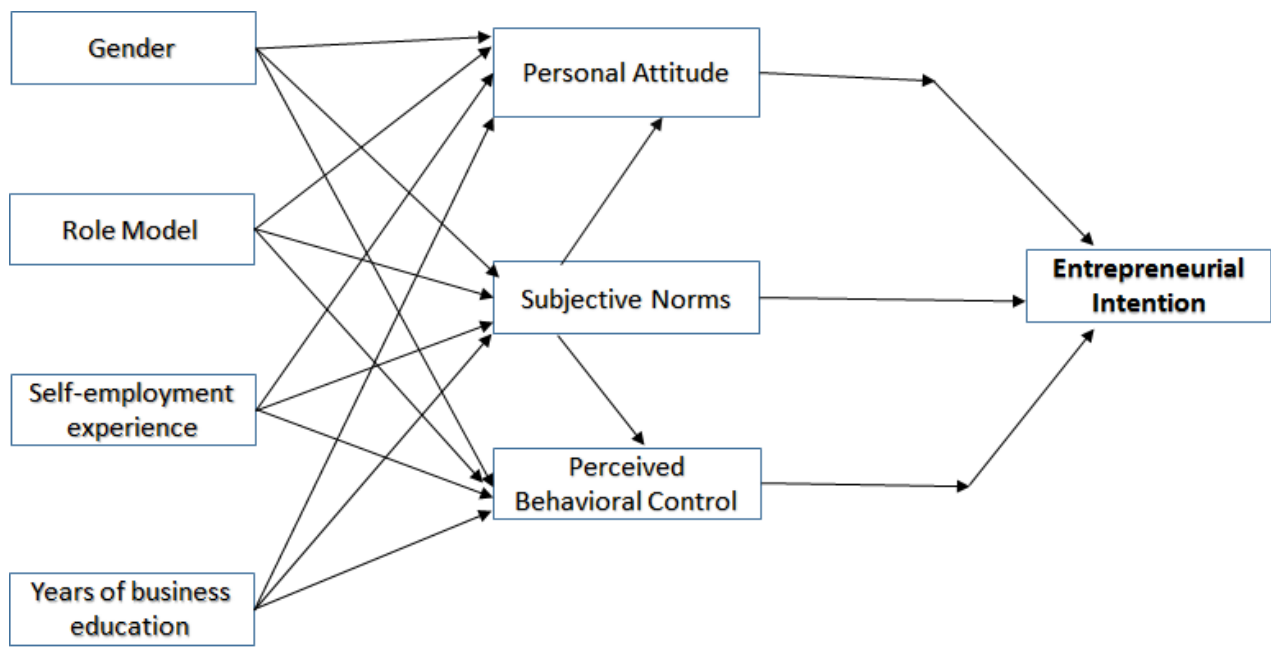

Figure 1. Entrepreneurial Intention Model (Adapted from Liñán and Chen (2006)).

\subsection{Descriptive Statistics}

A total of 555 responses were received from various universities in Saudi Arabia and India. As mentioned earlier, the application of inclusion and exclusion criteria finally yielded 535 valid responses. The summary of responses is presented in Table 3. A total of $61.3 \%$ of the respondents were male, whereas $38.7 \%$ were female. The majority of respondents $(73.3 \%)$ did not possess self-employment experience. A total of $57.6 \%$ of respondents claimed to have a role-model. A total of $66.7 \%$ of respondents had received one to two years of business education, while the remaining had three to four years or more. Furthermore, the subsamples of India and Saudi Arabia are similar. The Pearson's chi-square tests for gender $(\chi 2(1, N=535)=0.556, p=0.451)$, self-employment $\left(\chi^{2}(1\right.$, $\mathrm{N}=535)=0.275, p=0.600)$, and role model $\left(\chi^{2}(1, \mathrm{~N}=535)=0.602, p=0.438\right)$ reveal that the difference between two subsamples is not significant.

\subsection{Measurement Model}

Analysis of the measurement model showed that the 19 indicators out of 20 have loadings above 0.7 . Only PA1 has a value of 0.604 and is dropped. The model is rerun after removing the PA1, and results are reported in Table 4 . All items were found to be significant based on the bootstrapping procedure. The values of AVE and composite reliability (shown in Table 4) show acceptable loading for all of the items. The composite reliability scores are above 0.85 [116]. The values of AVE were above 0.5 , indicating acceptable convergent validity [116]. 
Table 3. Descriptive statistics.

\begin{tabular}{|c|c|c|c|c|c|c|c|}
\hline & & \multicolumn{2}{|c|}{ India } & \multicolumn{2}{|c|}{ Saudi Arabia } & \multicolumn{2}{|c|}{ Total } \\
\hline & & Count & Percent & Count & Percent & Count & Percent \\
\hline \multirow{2}{*}{ Gender } & Male & 170 & $59.60 \%$ & 158 & $63.2 \%$ & 328 & $61.3 \%$ \\
\hline & Female & 115 & $40.40 \%$ & 92 & $36.8 \%$ & 207 & $38.7 \%$ \\
\hline \multirow{2}{*}{ Self-employment } & Yes & 73 & $25.60 \%$ & 70 & $28.0 \%$ & 143 & $26.7 \%$ \\
\hline & No & 212 & $74.40 \%$ & 180 & $72.0 \%$ & 392 & $73.3 \%$ \\
\hline \multirow{2}{*}{ Role model } & Yes & 169 & $59.30 \%$ & 139 & $55.6 \%$ & 308 & $57.6 \%$ \\
\hline & No & 116 & $40.70 \%$ & 111 & $44.4 \%$ & 227 & $42.4 \%$ \\
\hline \multirow{3}{*}{$\begin{array}{l}\text { Years of Business } \\
\text { Education }\end{array}$} & $1-2$ & 189 & $66.30 \%$ & 168 & $67.2 \%$ & 357 & $66.7 \%$ \\
\hline & $3-4$ & 61 & $21.40 \%$ & 79 & $31.6 \%$ & 140 & $26.2 \%$ \\
\hline & 5 and above & 35 & $12.30 \%$ & 3 & $1.2 \%$ & 38 & $7.1 \%$ \\
\hline
\end{tabular}

Table 4. Measurement Model: Reliability and Validity (Total Sample).

\begin{tabular}{|c|c|c|c|}
\hline Construct/Indicators & Outer Loadings * & Composite Reliability * & AVE * \\
\hline Entrepreneurial Intention & & 0.930 & 0.741 \\
\hline EI1 & 0.819 & & \\
\hline EI2 & 0.861 & & \\
\hline EI3 & 0.873 & & \\
\hline EI4 & 0.909 & & \\
\hline EI5 & 0.847 & & \\
\hline EI6 & 0.852 & & \\
\hline Personal Attitude & & 0.865 & 0.713 \\
\hline PA2 & 0.843 & & \\
\hline PA3 & 0.788 & & \\
\hline PA4 & 0.878 & & \\
\hline PA5 & 0.865 & & \\
\hline $\begin{array}{l}\text { Perceived Behavioral } \\
\text { Control }\end{array}$ & & 0.886 & 0.639 \\
\hline PBC1 & 0.730 & & \\
\hline PBC2 & 0.855 & & \\
\hline PBC3 & 0.865 & & \\
\hline PBC4 & 0.827 & & \\
\hline PBC5 & 0.779 & & \\
\hline PBC6 & 0.727 & & \\
\hline Subjective Norms & & 0.763 & 0.678 \\
\hline SN1 & 0.792 & & \\
\hline SN2 & 0.853 & & \\
\hline SN3 & 0.824 & & \\
\hline
\end{tabular}

Note: ${ }^{*}$ Recommended values of outer loading (OL $\left.\geq 0.7\right)$, composite reliability (CR $\left.\geq 0.85\right)$, average variance extracted (AVE $\geq 0.5)$. 
The discriminant validity is presented in Table 5. The matrix comprises AVE values in diagonal positions, and below, squared correlations between each pair of constructs are given. The discriminant validity is adequate because the diagonal values are more than the values below (Fornell-Larcker criterion) [116].

Table 5. Discriminant validity (Total Sample).

\begin{tabular}{|c|c|c|c|c|c|c|c|c|}
\hline & EI & G & PBC & PA & $\mathbf{R M}$ & SEE & SN & YBE \\
\hline $\begin{array}{l}\text { Entrepreneurial } \\
\text { Intention (EI) }\end{array}$ & 0.861 & & & & & & & \\
\hline Gender $(\mathrm{G})$ & 0.151 & 1 & & & & & & \\
\hline $\begin{array}{c}\text { Perceived Behavioral } \\
\text { Control (PBC) }\end{array}$ & 0.498 & 0.11 & 0.799 & & & & & \\
\hline Personal Attitude (PA) & 0.655 & 0.059 & 0.353 & 0.844 & & & & \\
\hline Role Model (RM) & 0.178 & 0.071 & 0.157 & 0.066 & 1 & & & \\
\hline $\begin{array}{l}\text { Self-employment } \\
\text { Experience (SEE) }\end{array}$ & 0.149 & 0.107 & 0.171 & 0.141 & 0.125 & 1 & & \\
\hline Subjective Norms (SN) & 0.274 & 0.05 & 0.194 & 0.339 & 0.015 & 0.023 & 0.823 & \\
\hline $\begin{array}{l}\text { Years of Business } \\
\text { Education (YBE) }\end{array}$ & 0.009 & -0.126 & 0.139 & -0.022 & 0.153 & 0.006 & 0.03 & 1 \\
\hline
\end{tabular}

\subsection{Structural Model}

As described above, the reliability and validity of the measurement model is established. Therefore, analysis of the structural model is done at this stage. In this procedure, "coefficient of determination (R-square) for endogenous variables, path coefficients, and statistical significance through bootstrapping" are analyzed. This analysis was done for the total sample as well as the subsamples of each country. The results based on the total sample are shown in Figure 2. R-square values are present inside the circles that range from moderate to weak in strength [116]. Furthermore, the results of the total sample, and Indian and Saudi subsamples are shown in Tables 6 and 7. The paths with a value of $p>0.05$ are significant. A negative value seen in the case of gender-personal attitude indicates a negative influence. Further, the value of cross-validated redundancy index $\left(Q^{2}\right)$ is more than 0 in all the samples except for subjective norms (shown in Table 7. The values indicate that "the predictive relevance of the model" is established [122]. In the Indian subsample, the predictive relevance of the subjective norm is established, but in the total sample and Saudi subsample, it is not established. 


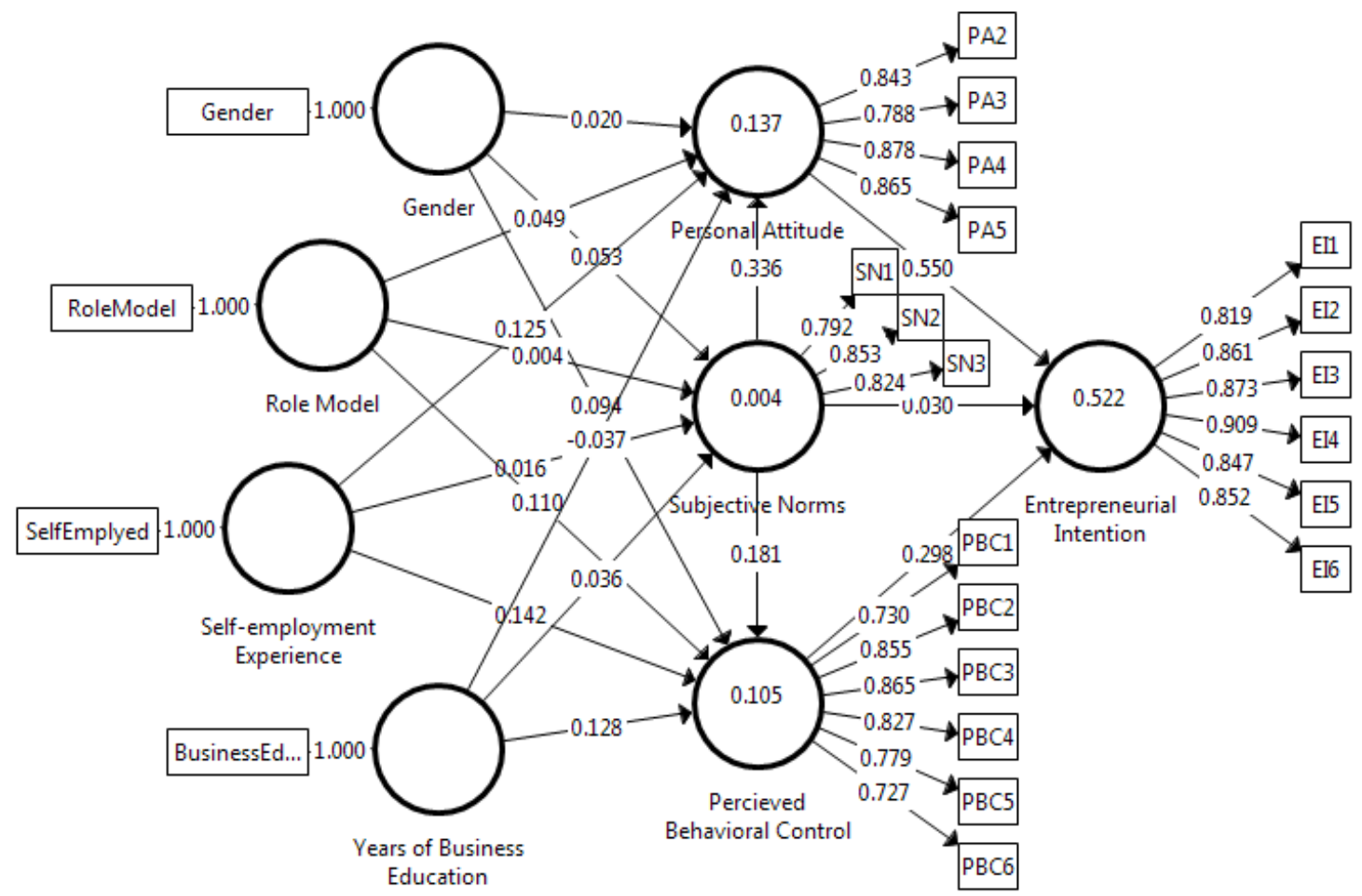

Figure 2. SEM results (total sample).

Table 6. Direct effects. Bias-corrected 95\% confidence intervals and indirect effect multigroup comparison results.

\begin{tabular}{|c|c|c|c|c|c|c|c|c|c|}
\hline \multirow[b]{2}{*}{ (Hypotheses) Paths } & \multicolumn{3}{|c|}{ Total Sample } & \multicolumn{3}{|c|}{ India } & \multicolumn{3}{|c|}{ Saudi Arabia } \\
\hline & Path & $\mathbf{t}$ & $p$-Value & Path & $t$ & $p$-Value & Path & $t$ & $p$-Value \\
\hline (H4a) Gender $\rightarrow$ PA & 0.020 & 0.498 & 0.618 & 0.122 & 2.150 & 0.032 & -0.124 & 2.204 & 0.028 \\
\hline$(\mathrm{H} 5 \mathrm{a}) \mathrm{RM} \rightarrow \mathrm{PA}$ & 0.049 & 1.181 & 0.238 & 0.037 & 0.643 & 0.520 & 0.031 & 0.465 & 0.642 \\
\hline (H6a) $\mathrm{SEE} \rightarrow \mathrm{PA}$ & 0.125 & 3.504 & 0.000 & 0.177 & 3.804 & 0.000 & 0.067 & 1.193 & 0.233 \\
\hline$(\mathrm{H7a}) \mathrm{YBE} \rightarrow \mathrm{PA}$ & -0.037 & 0.869 & 0.385 & -0.086 & 1.597 & 0.110 & 0.042 & 0.664 & 0.506 \\
\hline$(\mathrm{H} 4 \mathrm{~b})$ Gender $\rightarrow \mathrm{SN}$ & 0.053 & 1.174 & 0.240 & 0.129 & 2.089 & 0.037 & -0.064 & 0.758 & 0.448 \\
\hline$(\mathrm{H} 5 \mathrm{~b}) \mathrm{RM} \rightarrow \mathrm{SN}$ & 0.004 & 0.079 & 0.937 & 0.094 & 1.538 & 0.124 & -0.090 & 1.158 & 0.247 \\
\hline (H6b) $\mathrm{SEE} \rightarrow \mathrm{SN}$ & 0.016 & 0.363 & 0.717 & -0.022 & 0.361 & 0.718 & 0.027 & 0.389 & 0.697 \\
\hline$(\mathrm{H} 7 \mathrm{~b}) \mathrm{YBE} \rightarrow \mathrm{SN}$ & 0.036 & 0.854 & 0.393 & 0.030 & 0.544 & 0.586 & 0.025 & 0.352 & 0.725 \\
\hline$(\mathrm{H} 4 \mathrm{c})$ Gender $\rightarrow \mathrm{PBC}$ & 0.094 & 2.251 & 0.024 & 0.229 & 4.237 & 0.000 & -0.029 & 0.449 & 0.653 \\
\hline$(\mathrm{H} 5 \mathrm{c}) \mathrm{RM} \rightarrow \mathrm{PBC}$ & 0.110 & 2.519 & 0.012 & 0.001 & 0.026 & 0.979 & 0.179 & 2.964 & 0.003 \\
\hline$(\mathrm{H} 6 \mathrm{c}) \mathrm{SEE} \rightarrow \mathrm{PBC}$ & 0.142 & 3.432 & 0.001 & 0.135 & 2.657 & 0.008 & 0.210 & 3.605 & 0.000 \\
\hline$(\mathrm{H7c}) \mathrm{YBE} \rightarrow \mathrm{PBC}$ & 0.128 & 3.212 & 0.001 & 0.087 & 1.740 & 0.082 & 0.197 & 3.023 & 0.003 \\
\hline$(\mathrm{H} 2 \mathrm{~b}) \mathrm{SN} \rightarrow \mathrm{PA}$ & 0.336 & 6.886 & 0.000 & 0.393 & 6.454 & 0.000 & 0.194 & 2.059 & 0.040 \\
\hline$(\mathrm{H} 2 \mathrm{c}) \mathrm{SN} \rightarrow \mathrm{PBC}$ & 0.181 & 3.913 & 0.000 & 0.396 & 6.810 & 0.000 & 0.116 & 1.605 & 0.108 \\
\hline$(\mathrm{H} 1) \mathrm{PA} \rightarrow \mathrm{EI}$ & 0.550 & 13.189 & 0.000 & 0.566 & 9.638 & 0.000 & 0.500 & 8.580 & 0.000 \\
\hline$(\mathrm{H} 2 \mathrm{a}) \mathrm{SN} \rightarrow \mathrm{EI}$ & 0.030 & 0.686 & 0.493 & 0.136 & 2.342 & 0.019 & -0.131 & 2.229 & 0.026 \\
\hline$(\mathrm{H} 2) \mathrm{PBC} \rightarrow \mathrm{EI}$ & 0.298 & 7.923 & 0.000 & 0.242 & 4.395 & 0.000 & 0.318 & 5.664 & 0.000 \\
\hline
\end{tabular}


Table 7. $R^{2}$ and $Q^{2}$ indicators (in Total $N=535$, in India $N=285$, in Saudi Arabia $N=250$ ).

\begin{tabular}{|c|c|c|c|c|c|c|}
\hline \multicolumn{3}{|c|}{ Total Sample } & \multicolumn{2}{|c|}{ India } & \multicolumn{2}{|c|}{ Saudi Arabia } \\
\hline & $\mathbf{R}^{2}$ & $Q^{2}$ & $\mathbf{R}^{2}$ & $Q^{2}$ & $\mathbf{R}^{2}$ & $\mathrm{Q}^{2}$ \\
\hline Personal Attitude (PA) & 0.137 & 0.094 & 0.234 & 0.169 & 0.065 & 0.030 \\
\hline Subjective Norms (SN) & 0.004 & -0.002 & 0.028 & 0.012 & 0.014 & -0.002 \\
\hline Perceived Behavioral Control (PBC) & 0.105 & 0.064 & 0.270 & 0.168 & 0.142 & 0.074 \\
\hline Entrepreneurial Intention (EI) & 0.522 & 0.381 & 0.644 & 0.516 & 0.412 & 0.263 \\
\hline
\end{tabular}

\subsection{Multigroup Analysis}

The "measurement of invariance of composite model (MICOM)" analysis is a precondition for multigroup analysis [118]. MICOM establishes the measurement (outer) model invariance essential to carry out the multigroup analysis. This analysis is done in three steps, namely "configural invariance, compositional invariance, and invariance of mean and variance". The usage of SmartPLS itself ascertains the first step, the configural invariance [119]. The results of step two, the compositional invariance, are shown in Table 8. The permutation $p$-values are more than 0.05 , and the original correlation is greater than $5.0 \%$ quantile for all constructs; hence, the compositional invariance is established [120]. Further, in step three, invariance of mean and variance both are not established for some constructs (Table 9). Hence it can be concluded that a partial invariance is established, sufficient to carry out the multigroup analysis. Table 10 shows the path coefficient of both subsamples, their differences and significance of difference. The paths having $p$-value greater than 0.05 have significant differences between the subsamples such as gender and personal attitude.

Table 8. Measurement invariance test: step two compositional invariance.

\begin{tabular}{cccccc}
\hline Constructs & $\begin{array}{c}\text { Original } \\
\text { Correlation }\end{array}$ & $\begin{array}{c}\text { Correlation } \\
\text { Permutation Mean }\end{array}$ & $\mathbf{5 . 0 \% \text { Quantile }}$ & $\begin{array}{c}\text { Permutation } \\
\boldsymbol{p} \text {-Values }\end{array}$ & $\begin{array}{c}\text { Compositional } \\
\text { Invariance }\end{array}$ \\
\hline $\begin{array}{c}\text { Entrepreneurial } \\
\text { Intention }\end{array}$ & 1.000 & 1.000 & 1.000 & 0.122 & Yes \\
\hline Gender & 1.000 & 1.000 & 1.000 & 0.385 & 0.564 \\
\hline $\begin{array}{c}\text { Perceived Behavioral } \\
\text { Control }\end{array}$ & 0.999 & 0.999 & 0.997 & 0.388 & Yes \\
\hline $\begin{array}{c}\text { Personal Attitude } \\
\text { Role Model }\end{array}$ & 1.000 & 1.000 & 1.000 & 0.148 & Yes \\
\hline $\begin{array}{c}\text { Self-employment } \\
\text { Experience }\end{array}$ & 1.000 & 1.000 & 1.000 & 0.122 & Yes \\
\hline $\begin{array}{c}\text { Subjective Norms } \\
\begin{array}{c}\text { Years of Business } \\
\text { Education }\end{array}\end{array}$ & 0.999 & 1.000 & 0.987 & 0.749 & Yes \\
\hline
\end{tabular}


Table 9. Measurement invariance test: step three invariance of mean and variances.

\begin{tabular}{|c|c|c|c|c|c|c|c|c|}
\hline \multirow[t]{2}{*}{ Constructs } & \multirow{2}{*}{$\begin{array}{c}\text { Mean- } \\
\text { Original } \\
\text { Difference }\end{array}$} & \multicolumn{2}{|c|}{$\begin{array}{l}\text { 95\% Confidence } \\
\text { Interval }\end{array}$} & \multirow[t]{2}{*}{$\begin{array}{l}\text { Invariance } \\
\text { of Mean }\end{array}$} & \multirow[t]{2}{*}{$\begin{array}{l}\text { Variance- } \\
\text { Original } \\
\text { Difference }\end{array}$} & \multicolumn{2}{|c|}{$\begin{array}{l}\text { 95\% Confidence } \\
\text { Interval }\end{array}$} & \multirow[t]{2}{*}{$\begin{array}{l}\text { Invariance } \\
\text { of Variance }\end{array}$} \\
\hline & & $2.5 \%$ & $97.5 \%$ & & & $2.5 \%$ & $97.5 \%$ & \\
\hline $\begin{array}{l}\text { Entrepreneurial } \\
\text { Intention }\end{array}$ & -0.017 & -0.172 & 0.164 & Yes & 0.210 & -0.255 & 0.259 & Yes \\
\hline Gender & -0.073 & -0.165 & 0.174 & Yes & 0.034 & -0.079 & 0.079 & Yes \\
\hline $\begin{array}{c}\text { Perceived } \\
\text { Behavioral Control }\end{array}$ & 0.688 & -0.174 & 0.162 & No & -0.009 & -0.199 & 0.211 & Yes \\
\hline Personal Attitude & -0.240 & -0.176 & 0.166 & No & 0.213 & -0.336 & 0.339 & Yes \\
\hline Role Model & 0.075 & -0.168 & 0.166 & Yes & -0.023 & -0.049 & 0.054 & Yes \\
\hline $\begin{array}{l}\text { Self-employment } \\
\text { Experience }\end{array}$ & -0.054 & -0.173 & 0.167 & Yes & -0.056 & -0.180 & 0.180 & Yes \\
\hline Subjective Norms & -0.422 & -0.173 & 0.168 & No & 0.166 & -0.303 & 0.312 & Yes \\
\hline $\begin{array}{l}\text { Years of Business } \\
\text { Education }\end{array}$ & 0.058 & -0.170 & 0.167 & Yes & 0.792 & -0.275 & 0.273 & No \\
\hline
\end{tabular}

Table 10. Multigroup analysis (in India $N=285$, in Saudi Arabia $N=250$ ).

\begin{tabular}{cccccccc}
\hline $\begin{array}{c}\text { H8 on Different } \\
\text { Paths }\end{array}$ & Path (India) & Path (Saudi) & $\begin{array}{c}\text { Path } \\
\text { Difference }\end{array}$ & $\begin{array}{c}\text { Path Permutation } \\
\text { Mean Difference }\end{array}$ & 2.5\% & 97.5\% & $\begin{array}{c}\text { Permutation } \\
\boldsymbol{p} \text {-Values }\end{array}$ \\
\hline $\mathrm{Gender} \rightarrow \mathrm{PA}$ & 0.122 & -0.124 & 0.246 & 0.000 & -0.164 & 0.163 & 0.004 \\
\hline $\mathrm{RM} \rightarrow \mathrm{PA}$ & 0.037 & 0.031 & 0.006 & -0.001 & -0.168 & 0.163 & 0.947 \\
\hline $\mathrm{SEE} \rightarrow \mathrm{PA}$ & 0.177 & 0.067 & 0.110 & 0.001 & -0.143 & 0.138 & 0.122 \\
\hline $\mathrm{YBE} \rightarrow \mathrm{PA}$ & -0.086 & 0.042 & -0.128 & -0.002 & -0.172 & 0.171 & 0.147 \\
\hline $\mathrm{SN} \rightarrow \mathrm{PA}$ & 0.393 & 0.194 & 0.199 & 0.002 & -0.191 & 0.194 & 0.044 \\
\hline $\mathrm{Gender} \rightarrow \mathrm{SN}$ & 0.129 & -0.064 & 0.193 & 0.001 & -0.181 & 0.183 & 0.037 \\
\hline $\mathrm{RM} \rightarrow \mathrm{SN}$ & 0.094 & -0.090 & 0.184 & 0.002 & -0.179 & 0.185 & 0.048 \\
\hline $\mathrm{SEE} \rightarrow \mathrm{SN}$ & -0.022 & 0.027 & -0.050 & -0.001 & -0.177 & 0.176 & 0.576 \\
\hline $\mathrm{YBE} \rightarrow \mathrm{SN}$ & 0.030 & 0.025 & 0.006 & 0.002 & -0.163 & 0.170 & 0.945 \\
\hline $\mathrm{Gender} \rightarrow \mathrm{PBC}$ & 0.229 & -0.029 & 0.258 & 0.001 & -0.161 & 0.167 & 0.002 \\
\hline $\mathrm{RM} \rightarrow \mathrm{PBC}$ & 0.001 & 0.179 & -0.178 & -0.001 & -0.175 & 0.168 & 0.041 \\
\hline $\mathrm{SEE} \rightarrow \mathrm{PBC}$ & 0.135 & 0.210 & -0.075 & -0.002 & -0.163 & 0.158 & 0.372 \\
\hline $\mathrm{YBE} \rightarrow \mathrm{PBC}$ & 0.087 & 0.197 & -0.110 & -0.001 & -0.159 & 0.157 & 0.183 \\
\hline $\mathrm{SN} \rightarrow \mathrm{PBC}$ & 0.396 & 0.116 & 0.281 & -0.001 & -0.183 & 0.178 & 0.002 \\
\hline $\mathrm{PA} \rightarrow \mathrm{EI}$ & 0.566 & 0.500 & 0.067 & 0.001 & -0.168 & 0.170 & 0.440 \\
\hline $\mathrm{SN} \rightarrow \mathrm{EI}$ & 0.136 & -0.131 & 0.267 & 0.000 & -0.165 & 0.163 & 0.002 \\
\hline $\mathrm{PBC} \rightarrow \mathrm{EI}$ & 0.242 & 0.318 & -0.076 & -0.001 & -0.157 & 0.150 & 0.335 \\
\hline
\end{tabular}

\section{Discussion and Conclusions}

There were two main objectives of this study-first, to test if the EIM can predict the EI in a sample from two different countries; second, to test if the country variable makes a significant difference to any of the hypothesized paths in the model. Student samples have been studied in numerous researches on entrepreneurial intention [20,48,56].

Overall, the EI of students in both samples show similar intention to start their own venture. In a study on Germany and Poland [109], the EI was found to be different. Socio- 
economic environment of the countries was hypothesized to be the reason for the variations. In another study [33], comparing students from both the USA and Turkey had a lower EI but higher PA.

Based on the analysis, we found that two antecedents of EI, namely PA and PBC, significantly impact the EI in individual samples of India and Saudi Arabia as well as the combined sample. A positive and significant influence of PA and PBC have been confirmed in several studies $[2,14,15,45]$. This study also reveals a similar influence of PA on EI (H1). It has been reported in several studies that PA is the strongest of the three predictors of EI [123-125]. This predictor has remained significant in varying cultural contexts, a proposition confirmed in other studies [9,126]. A nonsignificant role of $\mathrm{PBC}$ has also been found in few earlier studies [127]. Karimi et al. [128] point out that the role of PBC may be affected by the economic status of the country where the research was conducted. In a developed country, the students might feel more confident about their success, whereas in developing countries or underdeveloped countries, they might be less or not confident.

The antecedent SN failed to show any significant effect on EI in the combined sample in this study. Interestingly, the relationship SN-EI was found significant in both the samples individually. An earlier study on several countries including India [107] also found a similar relationship. In general, the effect of SN in predicting EI has generally been ambiguous [105,129,130]. Some studies confirmed a direct relationship of SN with EI [12,29], while others did not $[2,21]$. The varying results of SN have been thought to be influenced by culture. Article [131] mentions that Western cultures may have less dominant influence on future entrepreneurs compared to non-Western nations. Moriano [107] also supports the view that individualistic and collectivistic cultures will show different results on the entrepreneurial intention, especially the subjective norms. In individualistic countries like the USA, Germany, etc., subjective norms would not be significant, whereas in collectivistic countries like India and Russia, they would be significant. Considering this ambiguity, [14] postulated that $\mathrm{SN}$ might influence EI indirectly through PA and PBC. This study confirmed that SN does influence PA and PBC significantly. This is similar to earlier studies $[9,132]$. Linan and Santos [133] first proposed that this relationship should be included in the entrepreneurship intention model. [131] opine that the SN scale may also be required to be revisited, despite adequate factor loadings.

The entrepreneurial intention model is an adapted version of the TPB that retains the same predictors of EI. The results show that overall, the model explains the measured construct EI reasonably well $\left(\mathrm{R}_{\text {combined }}^{2}=0.522 ; \mathrm{R}_{\text {India }}^{2}=0.644 ; \mathrm{R}^{2}\right.$ Saudi $\left.=0.412\right)$. Similar findings have been reported earlier regarding the applicability of EIM in CIE research [20]. One of the distinguishing traits of culture is the individualism and collectivism dimension. Countries differ from each other on this dimension to different degrees. On the scale developed by Hofstede, India is a mix of individualism and collectivism, whereas Saudi Arabia is a highly collectivistic society. The current findings show that EIM explains the EI quite well with the least variance reported in Saudi Arabia. A study on Zambia [134], which is a collectivist society, also confirmed the same results. A comparative study of Poland and South Africa [108] confirmed the validity of TPB in samples from both countries. Furthermore, the country moderator significantly influenced the EI in the two studied countries, PA and PBC. In a study [107], per capita income of a country was found to influence EI. Similarly, for the current study, EI for Saudi Arabia is higher than for India, although marginally because the per capita income of Saudi Arabia is more than India. The $\mathrm{Q}^{2}$ values are all above zero, indicating that the model has good predictive value for individual as well as combined samples. PA and PBC were found to significantly influence EI across the samples.

The demographic factors and human capital variables considered in the model show mixed results. The Gender-PA (H4a) path was significant in India and Saudi samples individually, but there is no significant effect in the combined sample. Gender-SN (H4b) and Gender-PBC (H4c) were not found to be significant in any sample. In a study on Saudi students [75], gender was found to be significant. The effect of gender on the antecedents 
of EI have been found to be contradictory. Diaz-Garcia and Jimenez-Moreno [123] reported that gender was found significant in some studies and was not found significant in others. The article [134] opines that a lower EI for females may be because of experience, support or role models. Integrating these thoughts with the findings of the present study, it would be interesting to investigate a combined effect of gender with experience, social support and role models. It is possible there may be some new findings and implications.

Role model did not have a significant influence on either PA (H5a) or SN (H5b) in combined as well as individual samples. Bosma et al. [63] have suggested earlier that students or budding entrepreneurs do not take "icons" as their role models. Therefore, this variable needs to be defined more accurately in order to obtain a clearer picture of its role on EI. Bosma et al. found that an entrepreneurial role model is someone who the student/potential entrepreneur "knows personally and with whom he/she has frequent interactions". The role model just shows significant influence on PBC (H5c) in the Saudi sample. In another study in Saudi Arabia [126], the antecedent SN was influenced by role models.

Self-employment experience (SEE) has a significant impact on PA (H6a) and PBC (H6c) in the combined sample and individual samples, but the SEE-PA is not significant in the Saudi sample. Significant effects of SEE have been reported in earlier studies [64]. Years of business education have a significant influence on PBC in combined and Saudi samples only. As discovered in $[20,135]$, university support through education may significantly influence entrepreneurial attitude and perceived behavioral control. Education was found to influence PBC (H6c) in this study.

Cultural influence might be responsible for varying results in the two samples. The results of the multigroup analysis show the role of the country in the various paths between the predicting variables and the EI. Gender-PA, Gender-SN, Gender-PBC, SN-PA, RM$\mathrm{SN}, \mathrm{RM}-\mathrm{PBC}, \mathrm{SN}-\mathrm{PBC}$, and SN-EI relationships are significantly different for the two countries. The role of gender is perceived differently in both countries, and therefore, all the relationships between gender and predictors of EI are found to be significantly different. The same is the case with SN. In earlier studies, too, SN was influenced by country $[14,136]$.

\section{Implications}

The results contribute to the scarce literature on CIE research. Moreover, the comparison of India and Saudi Arabia makes the study much more interesting and important because both the countries differ substantially in terms of culture and still face the common economic challenge of unemployment. The validation of EIM in these two culturally different nations adds to the strength of the model. The results are also particularly important to the ministries, educational institutions, government bodies as well as financial institutions. For example, the ministry of education and universities can apply the findings to introduce more targeted entrepreneurship education that bolsters the EI. The findings can also aid educational institutions in improving the "intermediate processes" [137] leading to entrepreneurship. Actions that are relevant at a cross-cultural level can also be derived from the findings of this research-for example, inclusion of entrepreneurship courses in curricula that directly influences the perceived behavioral control [138]. The level of entrepreneurial intention measured in this study would help financial institutions in determining the current propensity for entrepreneurship that might translate into future need for financing.

The findings have multifold implications on the university support for entrepreneurship. We should update curricula to include entrepreneurial lessons in varying degrees, from full courses to short modules in various programs. A method of objective evaluation of the policies may also be developed by understanding the results in cross-cultural context. Each antecedent of EI and the model would reflect the propensity of the students to take entrepreneurship as their career. The effect of various types of interventions in curricula should also be examined to see what would result in the most positive outcomes. These interventions should also include training and interactions with successful entrepreneurs. 
The faculty exposure to a practical entrepreneurial ecosystem is also important. The faculty exert a strong influence on the students' career intentions and knowledge. In fact, their role in direct or indirect influence in the EIM should be explored. The results would help in devising a pedagogy that would result in increased interest of students in entrepreneurship. A "dual tutor system" [20] will be a good initiative by universities to positively influence entrepreneurial behavior. More specifically, there should be a strong focus on students who report an "indecisive attitude" [132] toward entrepreneurship.

The results of this study are pertinent to government agencies and ministries responsible for formulating policies in higher education. The policy makers should formulate policies that support entrepreneurship as a career option, as [20] point to the development of a "scientifically rational entrepreneurship course system". Profiling of the students is also possible by considering the overall model and the various variables. Accordingly, appropriate programs may be developed for students in different cultures and different behavioral traits. Further, there should be a synergy between the government and universities to educate the students about the available support to entrepreneurs in the form of soft skills as well as financial resources.

On a special note, the findings of this study related to gender are also worthy of attention. Adequate measures should be taken to develop a system that encourages positive entrepreneurial intention among females.

In terms of research implications, this study addresses the call for more research in the area of CIE that involves comparison of entrepreneurial behaviors across cultures. Both the countries considered for this research share common features with many other countries, especially in the broad category of "Asian culture". Therefore, there is a significant potential for generalizability of the results to such countries.

One of the limitations of the study is that the researchers could not apply random sampling, limiting the generalizability of results. Secondly, entrepreneurship can be pursued by other population groups. Because only university students were considered in this study, we cannot generalize the findings to other groups. Third, self-reporting research instruments do suffer from bias, and the results should be corroborated by other methods too. Policymakers need to be cautious in interpreting the results for application because the intention to start entrepreneurship might not always convert into a real act. Further longitudinal studies are required to understand the process of transformation of intention into action. However, even with the limitations, the current study applied all the scientific protocols so that the results are meaningful, the measurement of constructs meets standards, and the overall model is tested considering all parameters.

The entrepreneurial activities are one of the fundamental engines to drive economic growth and well-being of the people, thus supporting the goals of sustainable development. Entrepreneurs are the shining gems that carve out new opportunities for society. Therefore, institutional support is very essential to develop entrepreneurship. This study brings good comparative insights in two countries, namely India and Saudi Arabia, to develop and support the cause of entrepreneurship.

Author Contributions: Conceptualization, N.H., N.A., S.L.G., M.M.A. and I.A.; Data curation, M.M.A.; Formal analysis, N.A.; Funding acquisition, M.M.A.; Investigation, N.H.; Methodology, N.H., N.A. and S.L.G.; Resources, I.A.; Validation, N.H., N.A. and M.M.A.; Writing-original draft, N.H. and N.A.; Writing-review \& editing, N.H., N.A., S.L.G., M.M.A. and I.A. All authors have read and agreed to the published version of the manuscript.

Funding: This research was funded by Deanship of Scientific Research, King Khalid University, Abha, grant number R.G.P.2/205/42.

Institutional Review Board Statement: Not applicable.

Informed Consent Statement: Informed consent was obtained from all the respondents who participated in the study.

Data Availability Statement: Available upon request. 
Acknowledgments: We thank Umm Al-Qura University, King Khalid University and Birla Institute of Technology for their support in completing this research. We specifically thank all the students who participated in the survey.

Conflicts of Interest: The authors declare that there is no conflict of interest.

\section{References}

1. González-Serrano, M.H.; González-García, R.J.; Carvalho, M.J.; Calabuig, F. Predicting entrepreneurial intentions of sports sciences students: A cross-cultural approach. J. Hosp. Leis. Sport Tour. Educ. 2021, 29, 100322. [CrossRef]

2. Leiva, J.C.; Mora-Esquivel, R.; Krauss-Delorme, C.; Bonomo-Odizzio, A.; Solís-Salazar, M. Entrepreneurial intention among Latin American university students. Acad. Rev. Latinoam. Adm. 2021, 34, 399-418. [CrossRef]

3. Guerrero, M.; Rialp, J.; Urbano, D. The impact of desirability and feasibility on entrepreneurial intentions: A structural equation model. Int. Entrep. Manag. J. 2008, 4, 35-50. [CrossRef]

4. Ceresia, F.; Mendola, C. Am I an Entrepreneur? Entrepreneurial Self-Identity as an Antecedent of Entrepreneurial Intention. Adm. Sci. 2020, 10, 46. [CrossRef]

5. Desa, U.N. Others Transforming Our World: The 2030 Agenda for Sustainable Development. Available online: https://stgwedocs.unep.org/bitstream/handle/20.500.11822/11125/unepswiosm1inf7sdg.pdf?sequence=1 (accessed on 5 June 2020).

6. Al-Mamary, Y.H.S.; Abdulrab, M.; Alwaheeb, M.A.; Alshammari, N.G.M. Factors impacting entrepreneurial intentions among university students in Saudi Arabia: Testing an integrated model of TPB and EO. Educ. Train. 2020, 62, 779-803. [CrossRef]

7. Ezeh, P.C.; Nkamnebe, A.D.; Omodafe, U.P. Determinants of entrepreneurial intention among undergraduates in a Muslim community. Manag. Res. Rev. 2019, 43, 1013-1030. [CrossRef]

8. Lee, S.M.; Lim, S.-B.; Pathak, R.D.; Chang, D.; Li, W. Influences on students attitudes toward entrepreneurship: A multi-country study. Int. Entrep. Manag. J. 2006, 2, 351-366. [CrossRef]

9. Trivedi, R.H. Entrepreneurial-intention constraint model: A comparative analysis among post-graduate management students in India, Singapore and Malaysia. Int. Entrep. Manag. J. 2017, 13, 1239-1261. [CrossRef]

10. Esfandiar, K.; Sharifi-Tehrani, M.; Pratt, S.; Altinay, L. Understanding entrepreneurial intentions: A developed integrated structural model approach. J. Bus. Res. 2019, 94, 172-182. [CrossRef]

11. Krueger, N. Entrepreneurial Intentions are Dead: Long Live Entrepreneurial Intentions. In Understanding the Entrepreneurial Mind; Springer: Cham, Switzerland, 2009.

12. Kautonen, T.; Van Gelderen, M.; Fink, M. Robustness of the Theory of Planned Behavior in Predicting Entrepreneurial Intentions and Actions. Entrep. Theory Pract. 2015, 39, 655-674. [CrossRef]

13. Ajzen, I. The theory of planned behavior. Organ. Behav. Hum. Decis. Process. 1991, 50, 179-211. [CrossRef]

14. Liñán, F.; Chen, Y. Development and Cross-Cultural Application of a Specific Instrument to Measure Entrepreneurial Intentions. Entrep. Theory Pr. 2009, 33, 593-617. [CrossRef]

15. Doanh, D.C.; Bernat, T. Entrepreneurial self-efficacy and intention among Vietnamese students: A meta-analytic path analysis based on the theory of planned behavior. Procedia Comput. Sci. 2019, 159, 2447-2460. [CrossRef]

16. Zhang, F.; Wei, L.; Sun, H.; Tung, L.C. How entrepreneurial learning impacts one's intention towards entrepreneurship: A planned behavior approach. Chinese Manag. Stud. 2019, 13, 146-170. [CrossRef]

17. Joensuu-Salo, S.; Viljamaa, A.; Varamäki, E. Do intentions ever die? The temporal stability of entrepreneurial intention and link to behavior. Educ. Train. 2020, 62, 325-338. [CrossRef]

18. Ali, J.; Jabeen, Z. Understanding entrepreneurial behavior for predicting start-up intention in India: Evidence from global entrepreneurship monitor (GEM) data. J. Public Aff. 2020, 2000, e2399. [CrossRef]

19. Farooq, M.S.; Salam, M.; ur Rehman, S.; Fayolle, A.; Jaafar, N.; Ayupp, K. Impact of support from social network on entrepreneurial intention of fresh business graduates: A structural equation modelling approach. Educ. Train. 2018, 60, 335-353. [CrossRef]

20. Su, Y.; Zhu, Z.; Chen, J.; Jin, Y.; Wang, T.; Lin, C.-L.; Xu, D. Factors Influencing Entrepreneurial Intention of University Students in China: Integrating the Perceived University Support and Theory of Planned Behavior. Sustainability 2021, 13, 4519. [CrossRef]

21. Maaloui, A.; Pérez, C.; Bertrand, G.; Razgallah, M.; Germon, R. "Cruel intention" or "entrepreneurial intention": What did you expect? An overview of research on entrepreneurial intention-An interactive perspective. In A Research Agenda for Entrepreneurial Cognition and Intention; Edward Elgar Publishing: Cheltenham, UK, 2018; pp. 7-46.

22. Baughn, C.C.; Chua, B.; Neupert, K.E. The Normative Context for Women's Participation in Entrepreneruship: A Multicountry Study. Entrep. Theory Pr. 2006, 30, 687-708. [CrossRef]

23. Jones, M.; Coviello, N.; Tang, Y.K. International Entrepreneurship research (1989-2009): A domain ontology and thematic analysis. J. Bus. Ventur. 2011, 26, 632-659. [CrossRef]

24. Głodowska, A. Comparative International Entrepreneurship: Theoretical Framework and Research Development. Entrep. Bus. Econ. Rev. 2019, 7, 235-248. [CrossRef]

25. Fuentes, H.B.; Hormiga, E.; Miravitlles, P.; Mesa, F.B. International entrepreneurship: A critical review of the research field. Eur. J. Int. Manag. 2019, 13, 381. [CrossRef]

26. Terjesen, S.; Hessels, J.; Li, D. Comparative International Entrepreneurship. J. Manag. 2016, 42, 299-344. [CrossRef]

27. Ward, A.; Hernández-Sánchez, B.; Sánchez-García, J. Entrepreneurial Intentions in Students from a Trans-National Perspective. Adm. Sci. 2019, 9, 37. [CrossRef] 
28. Liñán, F.; Krueger, N. British and Spanish Entrepreneurial Intentions: A Comparative Study. Rev. Econ. Mund. 2013, 33, 73-103.

29. Ward, A.; Hernández-Sánchez, B.R.; Sánchez-García, J.C. Entrepreneurial Potential and Gender Effects: The Role of Personality Traits in University Students' Entrepreneurial Intentions. Front. Psychol. 2019, 10, 2700. [CrossRef] [PubMed]

30. Hueso, J.A.; Jaén, I.; Liñán, F.; Basuki, W. The influence of collectivistic personal values on the formation of entrepreneurial intentions. Int. Small Bus. J. Res. Entrep. 2020, 38, 449-473. [CrossRef]

31. Paul, J.; Shrivatava, A. Do young managers in a developing country have stronger entrepreneurial intentions? Theory and debate. Int. Bus. Rev. 2016, 25, 1197-1210. [CrossRef]

32. Martínez-González, J.A.; Kobylinska, U.; García-Rodríguez, F.J.; Nazarko, L. Antecedents of Entrepreneurial Intention among Young People: Model and Regional Evidence. Sustainability 2019, 11, 6993. [CrossRef]

33. Ozaralli, N.; Rivenburgh, N.K. Entrepreneurial intention: Antecedents to entrepreneurial behavior in the U.S.A. and Turkey. J. Glob. Entrep. Res. 2016, 6, 1. [CrossRef]

34. GEM Consortium. How GEM Defines Entrepreneurship. Available online: https://www.gemconsortium.org/wiki/1149 (accessed on 15 September 2021).

35. Krueger, N.F., Jr.; Reilly, M.D.; Carsrud, A.L. Competing models of entrepreneurial intentions. J. Bus. Ventur. 2000, 15, 411-432. [CrossRef]

36. Luthje, C.; Franke, N. The 'making' of an entrepreneur: Testing a model of entrepreneurial intent among engineering students at MIT. RED Manag. 2003, 33, 135-147. [CrossRef]

37. Shapero, A.; Sokol, L. The Social Dimensions of Entrepreneurship. Available online: https:// ssrn.com/abstract=1497759 (accessed on 5 June 2020).

38. Granovetter, M.S. The Strength of Weak Ties. Am. J. Sociol. 1973, 78, 1360-1380. [CrossRef]

39. Audet, J. A Longitudinal Study of the Entrepreneurial Intentions of University Students. Acad. Entrep. J. $2004,10,3$.

40. Kolvereid, L.; Isaksen, E.J.; Mole, K.; Ram, M. The Psychology of the Entrepreneur. In Perspectives in Entrepreneurship; Springer Singapore: The Gateway, Singapore, 2012; pp. 27-39.

41. Fayolle, A.; Liñán, F. The future of research on entrepreneurial intentions. J. Bus. Res. 2014, 67, 663-666. [CrossRef]

42. Autio, E.; Keeley, R.H.; Klofsten, M.; Ulfstedt, T. Entrepreneurial Intent among Students: Testing an Intent Model in Asia, Scandinavia, and USA. Available online: https: / / www.diva-portal.org/smash / record.jsf?pid=diva2\%3A609927\&dswid=5906 (accessed on 5 June 2020).

43. Engle, R.L.; Dimitriadi, N.; Gavidia, J.V.; Schlaegel, C.; Delanoe, S.; Alvarado, I.; He, X.; Buame, S.; Wolff, B. Entrepreneurial intent: A twelve-country evaluation of Ajzen's model of planned behavior. Team Perform. Manag. 2010, 16, 35-57. [CrossRef]

44. Lortie, J.; Castogiovanni, G. The theory of planned behavior in entrepreneurship research: What we know and future directions. Int. Entrep. Manag. J. 2015, 11, 935-957. [CrossRef]

45. Koe, W.-L. The relationship between Individual Entrepreneurial Orientation (IEO) and entrepreneurial intention. J. Glob. Entrep. Res. 2016, 6, 13. [CrossRef]

46. Sandhu, M.S.; Sidique, S.; Riaz, S. Entrepreneurship barriers and entrepreneurial inclination among Malaysian postgraduate students. Int. J. Entrep. Behav. Res. 2011, 17, 428-449. [CrossRef]

47. Muhammad, A.D.; Aliyu, S.; Ahmed, S. Entreprenuerial Intention among Nigerian University Students. Am. J. Bus. Educ. (AJBE) 2015, 8, 239-248. [CrossRef]

48. Vamvaka, V.; Stoforos, C.; Palaskas, T.; Botsaris, C. Attitude toward entrepreneurship, perceived behavioral control, and entrepreneurial intention: Dimensionality, structural relationships, and gender differences. J. Innov. Entrep. 2020, 9, 1-26. [CrossRef]

49. Liñán, F.; Urbano, D.; Guerrero, M. Regional variations in entrepreneurial cognitions: Start-up intentions of university students in Spain. Entrep. Reg. Dev. 2011, 23, 187-215. [CrossRef]

50. Phong, N.D.; Thao, N.T.P.; Nguyen, N.P. Entrepreneurial intent of business students: Empirical evidence from a transitional economy. Cogent Bus. Manag. 2020, 7, 7. [CrossRef]

51. Yu, T.; Khalid, N.; Ahmed, U. Factors Influencing Entrepreneurial Intention among Foreigners in Kazakhstan. Sustainability 2021, 13, 7066. [CrossRef]

52. Ahmad, N.H.; Ramayah, T.; Mahmud, I.; Musa, M.; Anika, J.J. Entrepreneurship as a preferred career option: Modelling tourism students' entrepreneurial intention. Educ. Train. 2019, 61, 1151-1169. [CrossRef]

53. Pauceanu, A.M.; Alpenidze, O.; Edu, T.; Zaharia, R.M. What Determinants Influence Students to Start Their Own Business? Empirical Evidence from United Arab Emirates Universities. Sustainability 2018, 11, 92. [CrossRef]

54. Bogatyreva, K.; Edelman, L.F.; Manolova, T.S.; Osiyevskyy, O.; Shirokova, G. When do entrepreneurial intentions lead to actions? The role of national culture. J. Bus. Res. 2019, 96, 309-321. [CrossRef]

55. Liñán, F.; Moriano, J.A.; Jaén, I. Individualism and entrepreneurship: Does the pattern depend on the social context? Int. Small Bus. J. Res. Entrep. 2016, 34, 760-776. [CrossRef]

56. von Arnim, L.; Mrozewski, M. Entrepreneurship in an increasingly digital and global world. Evaluating the role of digital capabilities on international entrepreneurial intention. Sustainability 2020, 12, 7984. [CrossRef]

57. Ferri, L.; Ginesti, G.; Spanò, R.; Zampella, A. Exploring the Entrepreneurial Intention of Female Students in Italy. J. Open Innov. Technol. Mark. Complex. 2018, 4, 27. [CrossRef] 
58. Hongdiyanto, C.; Teofilus, T.; Sutrisno, T.F.; Dewanti, P.S.P. The Effect of Entrepreneurial Learning towards Entrepreneurial Intention of Indonesian Women. J. Asian Financ. Econ. Bus. 2020, 7, 573-582. [CrossRef]

59. Tipu, S.A.A.; Ryan, J. Predicting entrepreneurial intentions from work values: Implications for stimulating entrepreneurship in UAE national youth. Manag. Decis. 2016, 54, 621-629. [CrossRef]

60. Sitaridis, I.; Kitsios, F. Entrepreneurship as a Career Option for Information Technology Students: Critical Barriers and the Role of Motivation. J. Knowl. Econ. 2019, 10, 1133-1167. [CrossRef]

61. Basow, S.A.; Howe, K.G. Role-Model Influence: Effects of Sex and Sex-Role Attitude in College Students. Psychol. Women Q. 1980, 4, 558-572. [CrossRef]

62. Yang, J.-H. The Effect of Role Model on Entrepreneurial Self-Efficacy and Entrepreneurial Intention: Focused on Korean and Chinese University Students. Asia-Pac. J. Bus. Ventur. Entrep. 2019, 14, 211-220.

63. Bosma, N.; Hessels, J.; Schutjens, V.; Van Praag, M.; Verheul, I. Entrepreneurship and role models. J. Econ. Psychol. 2012, 33, 410-424. [CrossRef]

64. E Gibson, D. Role models in career development: New directions for theory and research. J. Vocat. Behav. 2004, 65, 134-156. [CrossRef]

65. Nowiński, W.; Haddoud, M.Y. The role of inspiring role models in enhancing entrepreneurial intention. J. Bus. Res. 2019, 96, 183-193. [CrossRef]

66. Zapkau, F.B.; Schwens, C.; Kabst, R. The Role of Prior Entrepreneurial Exposure in the Entrepreneurial Process: A Review and Future Research Implications. J. Small Bus. Manag. 2016, 55, 56-86. [CrossRef]

67. Fitzsimmons, J.; Douglas, E. Interaction between feasibility and desirability in the formation of entrepreneurial intentions. J. Bus. Ventur. 2011, 26, 431-440. [CrossRef]

68. Garaika, G.; Margahana, H.M.; Negara, S.T. Self efficacy, self personality and self confidence on entrepreneurial intention: Study on young enterprises. J. Entrep. Educ. 2019, 22, 1-12.

69. LaViolette, E.M.; Lefebvre, M.R.; Brunel, O. The impact of story bound entrepreneurial role models on self-efficacy and entrepreneurial intention. Int. J. Entrep. Behav. Res. 2012, 18, 720-742. [CrossRef]

70. Karimi, S.; Biemans, H.J.; Lans, T.; Chizari, M.; Mulder, M.; Mahdei, K.N. Understanding role Models and Gender Influences on Entrepreneurial Intentions Among College Students. Procedia Soc. Behav. Sci. 2013, 93, 204-214. [CrossRef]

71. Li, L.; Wu, D. Entrepreneurial education and students' entrepreneurial intention: Does team cooperation matter? J. Glob. Entrep. Res. 2019, 9, 35. [CrossRef]

72. Fellnhofer, K. Europe PMC Funders Group The Power of Passion in Entrepreneurship Education: Entrepreneurial Role Models Encourage Passion? J. Entrep. Educ. 2017, 20, 58-87.

73. Bignotti, A.; le Roux, I. Which types of experience matter? The role of prior start-up experiences and work experience in fostering youth entrepreneurial intentions. Int. J. Entrep. Behav. Res. 2020, 26, 1181-1198. [CrossRef]

74. Nguyen, X.T. Factors Affecting Entrepreneurial Decision of Nascent Entrepreneurs Belonging Generation Y in Vietnam. J. Asian Financ. Econ. Bus. 2020, 7, 407-417. [CrossRef]

75. Almobaireek, W.N.; Manolova, T.S. Who wants to be an entrepreneur? Entrepreneurial intentions among Saudi university students. Afr. J. Bus. Manag. 2012, 6, 4029-4040. [CrossRef]

76. Hockerts, K. Determinants of Social Entrepreneurial Intentions. Entrep. Theory Pr. 2017, 41, 105-130. [CrossRef]

77. Chlosta, S.; Patzelt, H.; Klein, S.B.; Dormann, C. Parental role models and the decision to become self-employed: The moderating effect of personality. Small Bus. Econ. 2010, 38, 121-138. [CrossRef]

78. Gird, A.; Bagraim, J.J. The Theory of Planned Behaviour as Predictor of Entrepreneurial intent amongst Final-Year University Students. S. Afr. J. Psychol. 2008, 38, 711-724. [CrossRef]

79. Lorz, M.; Mueller, S.; Volery, T. ENTREPRENEURSHIP EDUCATION: A SYSTEMATIC REVIEW OF THE METHODS IN IMPACT STUDIES. J. Enterprising Cult. 2013, 21, 123-151. [CrossRef]

80. Westhead, P.; Solesvik, M.Z. Entrepreneurship education and entrepreneurial intention: Do female students benefit? Int. Small Bus. J. 2016, 34, 979-1003. [CrossRef]

81. Badri, R.; Hachicha, N. Entrepreneurship education and its impact on students' intention to start up: A sample case study of students from two Tunisian universities. Int. J. Manag. Educ. 2019, 17, 182-190. [CrossRef]

82. Bae, T.J.; Qian, S.; Miao, C.; Fiet, J.O. The Relationship between Entrepreneurship Education and Entrepreneurial Intentions: A Meta-Analytic Review. Entrep. Theory Pr. 2014, 38, 217-254. [CrossRef]

83. Støren, L.A. Entrepreneurship in higher education: Impacts on graduates' entrepreneurial intentions, activity and learning outcome. Educ. Train. 2014, 56, 795-813. [CrossRef]

84. Perényi, Á.; Losoncz, M. A Systematic Review of International Entrepreneurship Special Issue Articles. Sustainability 2018, 10, 3476. [CrossRef]

85. Oviatt, B.M.; McDougall, P.P. Defining International Entrepreneurship and Modeling the Speed of Internationalization. Entrep. Theory Pract. 2005, 29, 537-553. [CrossRef]

86. Ahmed, F.U.; Brennan, L. A review of methodological diversity within the domain of international entrepreneurship. J. Int. Entrep. 2021, 19, 256-299. [CrossRef]

87. Zahra, S.A. A Conceptual Model of Entrepreneurship as Firm Behavior: A Critique and Extension. Entrep. Theory Pract. 1993, 17, 5-21. [CrossRef] 
88. McDougall, P.P.; Oviatt, B.M. International Entrepreneurship: The Intersection of Two Research Paths. Acad. Manag. J. 2000, 43, 902-906.

89. Coviello, N.E.; Jones, M.V. Methodological issues in international entrepreneurship research. J. Bus. Ventur. 2004, 19, 485-508. [CrossRef]

90. Servantie, V.; Cabrol, M.; Guieu, G.; Boissin, J.P. L'entrepreneuriat international est-il un champ? Une analyse bibliométrique de la littérature (1989-2015). J. Int. Entrep. 2016, 14, 168-212. [CrossRef]

91. The World Bank. Data Bank. Available online: https://databank.worldbank.org/metadataglossary/world-developmentindicators/series/SL.UEM.TOTL.NE.ZS (accessed on 15 September 2021).

92. International Monetary Fund. Real GDP Growth. Available online: https://www.imf.org/external/datamapper/NGDP_RPCH@ WEO/OEMDC/ADVEC/WEOWORLD (accessed on 30 September 2021).

93. International Labor Organization Key Indicators of the Labour Market (KILM). 2015. Available online: https://www.ilo.org/global/ statistics-and-databases/research-and-databases/kilm/WCMS_498929/lang--en/index.htm (accessed on 10 August 2021).

94. Bosma, N.; Hill, S.; Ionescu-Somers, A.; Kelley, D.; Levie, J.; Tarnawa, A. GEM—Global Entrepreneurship Monitor; GEM: London, UK, 2020; ISBN 9781916017825.

95. Global Entrepreneurship Monitor (GEM) Economy Profiles. Available online: https://www.gemconsortium.org/economyprofiles (accessed on 15 August 2021).

96. Bosma, N.; Hill, S.; Ionescu-Somers, A.; Kelley, D.; Guerrero, M.; Schott, T.; Ionescu-Somers, A. GEM Global Entrepreneurship Monitor 2020/2021: Global Report. Available online: https:/ / www.gemconsortium.org/report/gem-20202021-global-report (accessed on 15 August 2021).

97. Hofstede, G. Dimensionalizing Cultures: The Hofstede Model in Context. Online Read. Psychol. Cult. 2011, 2, 8. [CrossRef]

98. OECD. Real GDP Growth Forecast. Available online: https:// data.oecd.org/gdp/real-gdp-forecast.htm (accessed on 10 September 2021).

99. United Nations, WESP Country Classification. Available online: https://www.un.org/en/development/desa/policy/wesp/ wesp_current/2014wesp_country_classification.pdf (accessed on 10 September 2021).

100. International Labor Organization. ILO Stat Database. Available online: https://ilostat.ilo.org/topics/unemployment-andlabour-underutilization/ (accessed on 13 August 2021).

101. Global Entrepreneurship Monitor. Entrepreneurial Behavior and Attitudes. Available online: https://www.gemconsortium.org/ economy-profiles/saudi-arabia-2 (accessed on 13 August 2021).

102. Trading Economics. India Indicators. Available online: https://tradingeconomics.com/india/indicators (accessed on 13 August 2021).

103. Cruz, E.P.; Falcão, R.P.Q.; Barbosa, Y.O.F.; Paula, F.O. Analysis of prescribing variables of entrepreneurial intention of brazilian immigrants in Portugal. Rev. Adm. Contemp. 2020, 24, 349-368. [CrossRef]

104. De Pillis, E.; Reardon, K.K. The influence of personality traits and persuasive messages on entrepreneurial intention: A crosscultural comparison. Career Dev. Int. 2007, 12, 382-396. [CrossRef]

105. Liñán, F.; Chen, Y. Testing the Entrepreneurial Intention Model on a two-country Sample. Doc. Treb. 2006, 06/7, 1-37.

106. Uslay, C.; Teach, R.D.; Schwartz, R.G. Promoting Entrepreneurship for Economic Development: A Cross-Cultural Analysis of Student Attitudes. J. Res. Mark. Entrep. 2002, 4, 101-118. [CrossRef]

107. Moriano, J.A.; Gorgievski, M.; Laguna, M.; Stephan, U.; Zarafshani, K. A Cross-Cultural Approach to Understanding Entrepreneurial Intention. J. Career Dev. 2012, 39, 162-185. [CrossRef]

108. Nieuwenhuizen, C.; Swanepoel, E. Comparison of the entrepreneurial intent of master's business students in developing countries: South Africa and Poland. Acta Commer. 2015, 15, 1-10. [CrossRef]

109. Bouncken, R.B.; Zagvozdina, J.; Golze, A.; Mrozewska, A. A comparative study of cultural influences on intentions to found a new venture in Germany and Poland. Int. J. Bus. Glob. 2009, 3, 47. [CrossRef]

110. Brancu, L.; Gudmundsdóttir, S.; Gligor, D.; Munteanu, V. Is culture a moderator of entrepreneurship motivation? A comparative study of Romania and Iceland. Amfiteatru Econ. 2015, 17, 133-147.

111. Kibler, E.; Kautonen, T.; Fink, M. Regional Social Legitimacy of Entrepreneurship: Implications for Entrepreneurial Intention and Start-up Behaviour. Entrep. A Reg. Context 2017, 48, 57-77. [CrossRef]

112. Department of Higher Education; MoE, I. All India Higher Education Survey 2019-20; New Delhi. 2020. Available online: https://www.education.gov.in/sites/upload_files/mhrd/files/statistics-new/aishe_eng.pdf (accessed on 11 October 2021).

113. AllahMorad, S.; Zreik, S. Education in Saudi Arabia. Available online: https://wenr.wes.org/2020/04/education-in-saudi-arabia (accessed on 5 June 2020).

114. OECD. Stat Distribution of Graduates and New Entrants by Field. Available online: https://stats.oecd.org/Index.aspx? datasetcode=EAG_GRAD_ENTR_FIELD (accessed on 5 June 2020).

115. Alam, M.; Ahmad, N.; Naveed, Q.; Patel, A.; Abohashrh, M.; Khaleel, M. E-Learning Services to Achieve Sustainable Learning and Academic Performance: An Empirical Study. Sustainability 2021, 13, 2653. [CrossRef]

116. Hair, J.F.; Ringle, C.M.; Sarstedt, M. PLS-SEM: Indeed a Silver Bullet. J. Mark. Theory Pract. 2011, 19, 139-152. [CrossRef]

117. Ahmad, N.; Mehmood, R. Enterprise systems and performance of future city logistics. Prod. Plan. Control. 2016, 27, 500-513. [CrossRef] 
118. Henseler, J.; Ringle, C.M.; Sarstedt, M. Testing measurement invariance of composites using partial least squares. Int. Mark. Rev. 2016, 33, 405-431. [CrossRef]

119. Garson, G.D. Partial Least Squares: Regression E Structural Equation Models; Statistical Associates Publishing: Asheboro, NC, USA, 2016.

120. Wong, K.K.-K. Mastering Partial Least Squares Structural Equation Modeling (PLS-Sem) with Smartpls in 38 Hours; iUniverse: Bloomington, IN, USA, 2019.

121. Ringle, C.M.; Wende, S.; Becker, J.-M. SmartPLS 3 2015. Available online: http:/ / www.smartpls.com (accessed on 1 May 2021).

122. Chin, W.W. How to Write Up and Report PLS Analyses. In Handbook of Partial Least Squares; Esposito, V.V., Chin, W.W., Henseler, J., Wang, H., Eds.; Springer: Berlin/Heidelberg, Germany, 2010; pp. 655-690.

123. Díaz-García, M.C.; Jiménez-Moreno, J. Entrepreneurial intention: The role of gender. Int. Entrep. Manag. J. 2010, 6, 261-283. [CrossRef]

124. Moi, T.; Adeline, Y.L.; Dyana, M.L. Young adult responses to entrepreneurial intent. J. Arts, Sci. Commer. $2011,3,37$.

125. Pihie, Z.A.L. Entrepreneurship as a career choice: An analysis of entrepreneurial self-efficacy and intention of university students. Eur. J. Soc. Sci. 2009, 9, 338-349.

126. Naushad, M. A study on the antecedents of entrepreneurial intentions among Saudi students. Entrep. Sustain. Issues 2018, 5, 600-617. [CrossRef]

127. Shah, N.; Soomro, B.A. Investigating entrepreneurial intention among public sector university students of Pakistan. Educ. Train. 2017, 59, 841-855. [CrossRef]

128. Karimi, S.; Biemans, H.J.A.; Lans, T.; Chizari, M.; Mulder, M. The Impact of Entrepreneurship Education: A Study of Iranian Students' Entrepreneurial Intentions and Opportunity Identification. J. Small Bus. Manag. 2016, 54, 187-209. [CrossRef]

129. Ribeiro, E.M.P.; Gauntlett, D. Making is Connecting: The Social Meaning of Creativity, from DIY and Knitting to Youtube and Web 2.0. Comun. Soc. 2012, 22, 206-210. [CrossRef]

130. Shi, Y.; Yuan, T.; Bell, R.; Wang, J. Investigating the Relationship Between Creativity and Entrepreneurial Intention: The Moderating Role of Creativity in the Theory of Planned Behavior. Front. Psychol. 2020, 11, 1-12. [CrossRef] [PubMed]

131. Lee-Ross, D. An examination of the entrepreneurial intent of MBA students in Australia using the entrepreneurial intention questionnaire. J. Manag. Dev. 2017, 36, 1180-1190. [CrossRef]

132. Velásquez, J.A.T.; Arias, A.V.; Hernández, J.B.; Díez-Echavarría, L.; Marín, M.L.U.; Pérez, F.O.M. Characterization of entrepreneurial intention in university students as from Systemic Entrepreneurship Intention Model: A case study. Cuad. Gestión 2018, 18, 95-114. [CrossRef]

133. Liñán, F.; Santos, F.J. Does social capital affect entrepreneurial intentions? Int. Adv. Econ. Res. 2007, 13, 443-453. [CrossRef]

134. Mwiya, B.; Wang, Y.; Shikaputo, C.; Kaulungombe, B.; Kayekesi, M. Predicting the Entrepreneurial Intentions of University Students: Applying the Theory of Planned Behaviour in Zambia, Africa. Open J. Bus. Manag. 2017, 05, 592-610. [CrossRef]

135. Liñan, F.M.; Rodríguez-Cohard, J.C.; Rueda-Cantuche, J.M. Factors affecting entrepreneurial intention levels: A role for education. Int. Entrep. Manag. J. 2011, 7, 195-218. [CrossRef]

136. Kristiansen, S.; Indarti, N. Entrepreneurial intention among indonesian and norwegian students. J. Enterprising Cult. 2004, 12, 55-78. [CrossRef]

137. Fayolle, A.; Degeorge, J.M. Attitudes, Intentions and Behaviour: New Approaches to Evaluating Entrepreneurship Education. In International Entrepreneurship Education; Edward Elgar Publishing: Cheltenham, UK, 2006.

138. Israr, M.; Saleem, M. Entrepreneurial intentions among university students in Italy. J. Glob. Entrep. Res. 2018, 8, 20. [CrossRef] 